\title{
Os provedores da técnica: os engenheiros provinciais e a edificação da infraestrutura viária de Minas Gerais*
}

\author{
Purveyors of technology: provincial engineers and the \\ construction of road infrastructure in Minas Gerais
}

\author{
Lidiany Silva Barbosa \\ Pesquisadora associada ao Núcleo \\ de Pesquisa em História Econômica \\ e Demográfica do Centro de \\ Desenvolvimento e Planejamento \\ Regional de Minas Gerais/ \\ Universidade Federal de Minas \\ Gerais. \\ Rua Gonçalves Dias, 916/1002 \\ 30140-091 - Belo Horizonte \\ MG - Brasil \\ lidiany@cedeplar.ufmg.br
}

BARBOSA, Lidiany Silva. Os provedores da técnica: os engenheiros provinciais e a edificação da infraestrutura viária de Minas Gerais. História, Ciências, Saúde - Manguinhos, Rio de Janeiro, v.18, n.3, jul.-set. 2011, p.907-928.

Resumo

Analisa a atuação de engenheiros na constituição da infraestrutura viária de Minas Gerais entre as décadas de 1840 e 1880. Construir estradas e pontes e conservá-las com regularidade foi tarefa desempenhada pelo governo provincial mineiro que, desde a década de 1830 , contava com repartição voltada para projetar, edificar e manter vias de comunicação consideradas públicas. Os engenheiros inseriram-se nessa agência desde sua fundação, atuando de forma significativa na elaboração de projetos e na execução direta de determinadas obras. O estudo fundamenta-se na documentação administrativa que relatava ao governo provincial detalhes do andamento das obras. O acervo gerado no transcurso das intervenções oferece informações técnicas, administrativas, financeiras, da mão de obra e dos agentes envolvidos com as construções.

Palavras-chave: Construção de estradas e pontes; Minas Gerais; século XIX; engenheiros; infraestrutura viária.

\section{Abstract}

The article analyzes the role played by engineers in the construction of road infrastructure in Minas Gerais between the 1840s and 1880s. Building and providing regular maintenance for roads and bridges was a task carried out by the Minas Gerais provincial government, which since the 1830s had a specific agency assigned to designing, building, and maintaining public communication routes. Engineers were part of the agency from its inception, playing a significant role in designing projects and in the actual execution of certain works. The current study is grounded in administrative documentation in which the details of work progress are reported to the provincial government. The gathered records provide technical, administrative, and financial information, along with data on labor power and the agents engaged in construction works.

Keywords: road and bridge construction; Minas Gerais; nineteenth century; engineers; road infrastructure. 
$\mathrm{N}^{\mathrm{s}}$ o ano de 1942, o engenheiro civil Abel Reis, de Uberaba, encaminhou à $3^{a}$ Convenção Nacional de Engenheiros proposta para a escrita da história da engenharia no Brasil. Entre as justificativas arroladas, argumentou que "os engenheiros patrícios nossos antepassados têm realizado em vários pontos do vasto território nacional obras importantes, encerrando, muitas vezes, soluções originais e próprias" (Reis, 1942, p.25). O objetivo deste artigo está em sintonia com a sugestão noticiada há quase sete décadas pela Revista Mineira de Engenharia, já que busca apresentar elementos que contribuam para a história da infraestrutura viária implantada pelo governo provincial de Minas Gerais, sobretudo sobre os engenheiros ${ }^{1}$ envolvidos na construção e conservação das obras públicas que a compunham.

As fontes principais a embasar este estudo são dois conjuntos documentais que provavelmente conformam o maior acervo para o estudo da história da edificação e manutenção de estradas e pontes no Brasil do século XIX: "Processos de construção de estradas" e "Processos de construção de pontes". História que, por sua vez, tem os engenheiros como importantes protagonistas. Os conjuntos estão sob a guarda do Arquivo Público Mineiro, na Seção Provincial, e possuem como atributo marcante o largo recorte temporal (décadas de 1840-1880), volumosa massa documental (aproximadamente 24 mil documentos) e grande heterogeneidade temática. Se, por um lado, a soma dessas características implica dificuldades na sistematização e no exame da documentação, por outro, a qualidade das suas informações configura meio privilegiado para o conhecimento da história dos transportes viários de Minas Gerais, especialmente a história da edificação da infraestrutura viária e dos atores envolvidos nesse processo. Nessa medida, é necessário salientar dois aspectos. O primeiro em relação aos processos, fontes praticamente desconhecidas pelos pesquisadores da temática dos transportes, como atesta o rigoroso levantamento realizado por Queiroz (2000). Trata-se de documentação pouco conhecida a realçar realidade escassamente estudada uma vez que, quando se trata da história dos transportes no século XIX, estudos sobre ferrovias e temas que lhes são afins têm larga predominância frente aos dedicados às outras modalidades (Queiroz, 2000). O segundo aspecto tem relação com a atuação dos engenheiros em Minas Gerais. Os principais estudos que elegeram como objeto esses atores privilegiaram período posterior à fundação da Escola de Minas de Ouro Preto, ocorrida em outubro de 1876, de modo que, por meio das análises de Carvalho (2002), Barbosa (1993), Roque (1999) e Barbosa (2005) é possível recompor aspectos importantes do discurso e ação de professores e ex-alunos no final do século XIX e século XX adentro. Os processos falam da atuação dos engenheiros em período anterior à fundação da importante escola ouro-pretana.

Parte-se do suposto de que o conhecimento da formação histórica de Minas Gerais é fundamental para o entendimento do intenso processo de edificação e manutenção da rede viária levado a termo pelo governo provincial. Consequentemente, a explicação para existência de acervo tão extenso e abrangente encontra sua razão de ser na própria história da província. A necessidade de infraestrutura de transportes terrestres destaca-se em Minas Gerais em virtude de suas características geográficas e de seus atributos socioeconômicos como sua localização interior, a existência de grandes impedimentos à navegação fluvial, o dinamismo econômico (Martins, 1983), a maior concentração populacional do Império 
(Paiva, 1996), extensa rede urbana (Rodarte, 1999) e diversidade regional interna (Godoy, 1996). Em outros termos, propõe-se abordagem que considera que a riqueza das informações dos processos resulta de rotina administrativa que, em grande parte, foi determinada pelo contexto geográfico, econômico e social mineiro (Barbosa, 2008).

\section{Minas Gerais e suas necessidades viárias}

Em Minas Gerais, não só a localização interior, mas também a formação geográfica condicionaram o desenvolvimento dos transportes. A geografia do estado em linhas gerais, é marcada pela diversidade das formas do relevo, do clima, da hidrografia e de seus ecossistemas; variedade expressa pela convivência da sinuosidade topográfica das regiões centrais e do sul com os planaltos amenos das regiões do oeste e norte; pela coexistência de regime climático típico de zonas tropicais das regiões do leste com a agrestidade própria das zonas dos cerrados que se espraiam pelas regiões do norte e oeste; pela presença de importantes bacias hidrográficas, que definem rede hídrica fortemente capilarizada e com vários sentidos. ${ }^{2}$ Existem também multifacetados ecossistemas de matas, cerrados, campos, caatingas e carrascais, que se desdobram em inúmeros outros subecossistemas que imprimem caracteres originais a cada uma das regiões mineiras (Godoy, 1996). Como atenta Witold Kula (1974, p.521), os diferentes elementos que compõem a geografia de determinado espaço não são aspectos naturais, indiferentes das organizações sociais. Essa observação aparentemente simples é especialmente válida para o caso dos transportes, principalmente se considerados em uma sociedade pré-industrial, fortemente condicionados em sua estrutura e dinâmica por relevo, clima, hidrografia e vegetação.

No final do século XVII e início do seguinte, a descoberta de imenso e acessível manancial de riquezas minerais no interior da América portuguesa colocou em movimento processo que provocou profundas mudanças na economia e sociedade colonial. Desencadeou-se vertiginosa expansão demográfica causada pela corrida do ouro (Holanda, 2001, p.266). Consequência desse afluxo populacional para o interior da Colônia foi o rápido povoamento e a precoce criação de adensamentos urbanos. Nas seis primeiras décadas do século XVIII, em torno das minas, estabeleceu-se sociedade com fortes traços urbanos, com cidades integradas por rede de relações mercantis e sociais, atividades complementares e subsidiárias à extração aurífera e diamantífera e predomínio do trabalho escravo.

Desde o início da ocupação, começou a se esboçar diferenciação regional expressa em duas categorias de percepção geográfica: as minas e os sertões. A região das minas correspondia aos núcleos originais de ocupação, e a dos sertões recobria a zona curraleira (Carrara, 1997, p.49). Como referido, em Minas Gerais formou-se sociedade em torno da mineração e com base no trabalho escravo. No entanto, a centralidade da extração mineral não se constituiu em exclusividade. Mesmo que a atividade mineradora tenha definido o desenho da colonização e do povoamento, foi por meio das atividades agrícolas e comerciais que a sociedade mineira do Setecentos consolidou-se (Chaves, 1999, p.64). Portanto, ainda durante o período em que a mineração estava na sua fase de regular expansão, outras atividades, especialmente agropastoris, cumpriam papel significativo. Por exemplo, as principais unidades responsáveis pela produção na capitania, as fazendas, normalmente 
não se dedicavam apenas a uma atividade. Para esta realidade econômica, Miguel Costa Filho (1963, p.164) criou o conceito de 'fazenda mista', que compreendia as unidades produtivas em que a mineração coexistia com a agropecuária e atividades de transformação.

Entre a terceira quadra do século XVIII e o último quartel do século XIX, ou entre o início do irreversível declínio da economia do ouro e a crise do sistema escravista brasileiro, Minas Gerais desenvolveu economia preponderantemente não exportadora e com independência relativa em relação aos mercados externos de outros espaços regionais e do exterior do Brasil. Entre os séculos XVIII e XIX, a passagem da dinâmica economia escravista voltada para o mercado externo para economia escravista voltada para o mercado interno implicou a combinação de novas e velhas características. Na terceira quadra do século XVIII, com o declínio da atividade mineradora, redefiniu-se o papel que Minas Gerais desempenhava na economia colonial. Consolidaram-se a tendência à diversificação e a propensão ao abastecimento do mercado interno de Minas e de outras capitanias. Tendências estimuladas com o estabelecimento da Corte no Rio de Janeiro, quando a capital da Colônia passou a ser o principal mercado para os produtos de Minas Gerais (Almeida, 1995, p.106). Após o declínio da mineração, a constante expansão demográfica (Carrara, 1997, p.57-58), o prosseguimento da urbanização (Paula, 2000, p.63-65) e a reestruturação produtiva que se seguiu à desagregação da economia do ouro (Libby, 1988) são processos ligados à passagem da predominância dos mercados externos no aprovisionamento da capitania para o abastecimento preponderantemente realizado por sua produção interna.

Os resultados do declínio das atividades mineradoras e da decorrente inversão dos fluxos do comércio já estavam definidos na primeira quadra do século XIX. Alcança-se a quase autonomia no abastecimento de gêneros essenciais de consumo básico, sobretudo os agropecuários e da indústria rural, e permanece a dependência externa de itens não produzidos internamente, como escravos, sal e mercadorias europeias. A fazenda mista converteu-se em fazenda diversificada, tornando-se infrequente a conjugação da mineração com atividades agropecuárias e indústria rural. Consolidaram-se os fluxos de exportação, principalmente para o aprovisionamento do Rio de Janeiro (Lenharo, 1979). Minas Gerais continuou, século XIX adentro, com o maior número de núcleos urbanos e com a maior população do Brasil (Paula, 2000, p.34). Aprofundou-se e tornou-se mais nítido o processo de diferenciação regional iniciado no século XVIII (Godoy, 1996). Em resumo, forjaram-se e/ou conjugaram-se atributos como dinamismo econômico, expressiva presença relativa de população, dispersão e grande número de núcleos urbanos, condição interior, capilarizado comércio interno e externo, além da mencionada diversidade geográfica, que fizeram da existência de complexa infraestrutura viária um imperativo incontornável.

\section{O governo provincial de Minas Gerais e a imperativa infraestrutura viária}

O governo provincial de Minas Gerais atuou sobre essa diversa e complexa realidade e, em grande medida, tomou para si a responsabilidade de prover o espaço provincial de infraestrutura de transportes. As vias de comunicação mineiras eram predominantemente terrestres $^{3}$ - estradas, caminhos e picadas - e a partir delas se estruturaram os meios e 
instrumentos de transportes. ${ }^{4}$ Entre eles havia largo predomínio dos muares e das tropas como meios e formas responsáveis pelo deslocamento de pessoas e bens.

Edificar e manter rede viária em espaço provincial com as características de Minas Gerais representou considerável esforço administrativo, financeiro e político por parte do governo provincial mineiro e os "Processos de construção de estradas e pontes" são testemunhos desse empenho. Para tanto, desde a década de 1830, vigorava no organograma administrativo repartição que cuidaria exclusivamente das obras públicas provinciais, com grande destaque para as estradas e pontes.

A história da repartição que administrou e executou as obras públicas em Minas Gerais se insere em movimento mais amplo iniciado após a descentralização político-administrativa decorrente do ato adicional de 1834. A Secretaria de Obras Públicas estava integrada ao governo provincial de Minas Gerais como repartição pertencente ao Poder Executivo, sendo hierarquicamente subordinada à Presidência da Província (Tôrres, 1980, p.377-378). Sua criação data de 1835 , quando a lei 18 criou lugar no organograma administrativo provincial para repartição que cuidaria dos assuntos viários - a Inspetoria-Geral de Estradas. A lei de 1835 é marco importante, pois, durante duas décadas, foi a referência para a política de viação da província. Ela definiu normas técnicas para construção das estradas, regras de utilização das vias, critérios para o estabelecimento de barreiras e ainda arrojado plano viário para Minas Gerais. ${ }^{5}$ Com relação ao quadro de funcionários da agência, definiu o inspetor geral de estradas, três engenheiros e a polícia de estrada como seus componentes.

Decorridos quatro anos da publicação da lei de 1835 a função de inspetor-geral das estradas foi extinta e seus encargos passaram a ser exercidos pelo presidente da província (LLM, lei 154, art. 15, 1839). Quando o cargo de inspetor-geral foi recriado, em 1840, trouxe disposição legal destacável que sugeria ao presidente de província optar por indivíduo detentor de conhecimento de engenharia aplicada à construção de estradas e pontes (LLM, lei 187, 1840). Novamente, em 1842, o cargo foi suprimido e passou a vigorar determinação que delegou as funções ao presidente da província (LLM, lei 231, art. 1ํ, 1842).

Em 1857 foi restabelecida a Repartição Geral de Obras Públicas da província (LLM, Regulamento 39, 1857). A lei regulamentar que recriou a agência é um corpus normativo extenso e inovador e que pode ser tomado como outra baliza importante na institucionalização da repartição. Desde então, a repartição não se direcionava unicamente às estradas; suas atribuições alargaram-se e passaram a contemplar todas as obras públicas provinciais. Ela seria gerida por um inspetor-geral e um adjunto. A cargo do primeiro ficou extenso rol de funções (LLM, Regulamento 39, 1857, p.2-5). Em relação ao adjunto, a leitura de suas atribuições sugere que o cargo seria ocupado por um engenheiro, já que a lei determinou que "além dos deveres e obrigações dos demais engenheiros", lhe competiria: coadjuvar o inspetor-geral em todos os trabalhos técnicos a cargo da repartição; visitar e inspecionar as obras da capital; inspecionar a conservação, arranjo e boa guarda dos materiais da repartição; ajudar no aperfeiçoamento da carta da província. Notadamente com relação aos engenheiros e seus ajudantes, resolveu que "serão, na conformidade das ordens da Presidência, ou dos respectivos contratos, incumbidos pelo Inspetor Geral de estudar e organizar os projetos das obras públicas com os planos e orçamentos, e de dirigir e executar os trabalhos de construção, reparação e conservação em qualquer parte da 
Província, ou nos distritos que lhes forem especialmente designados, sendo neste caso considerados como inspetores deles" (LLM, Regulamento 39, art. 15, 1857).

Além disso, caberia aos engenheiros: indicar ao inspetor-geral, para que fossem propostos ao presidente de província, pessoas para administrar as obras públicas que estivessem sob sua imediata chefia; cuidar dos empregados e feitores sob sua imediata direção; prestar esclarecimentos para aperfeiçoamento da carta da província e apresentar relatório mensal de trabalho (LLM, Regulamento 39, 1857, p.7-8).

Determinadas normas para execução das obras, definidas pela lei regulamentar 39, foram reiteradas nos dispositivos legais posteriores, tais como a necessidade de liberação prévia do presidente da província para início de toda obra; a imprescindibilidade de plano e orçamento para se iniciar as construções e manutenções; a preferência, dentre as formas de administração da execução das obras (empreitada, arrematação ou empresa) ${ }^{6}$, pelos trabalhos não realizados diretamente pela província e, por fim, a sugestão do emprego de trabalhadores livres nas obras.

Passados dois anos após sua recriação, a repartição foi novamente suprimida, e seus expedientes incorporados à Secretaria de Governo (LLM, lei 1009, 1859, p.82). O órgão foi restabelecido em 1866 (LLM, Regulamento 53), quando se alterou sua designação para Diretoria de Obras Públicas da Província, aprimorou-se a estrutura organizacional e aumentou o número de engenheiros empregados na agência. Quanto à sua organização, a diretoria foi dividida em duas seções, a primeira denominada Geral Administrativa e a segunda Técnica. Na Seção Técnica foram alocados os engenheiros, e este setor respondeu pela maior parte das responsabilidades da repartição. Em relação ao trabalho do engenheiro, nota-se especialização funcional e ganho de influência na execução das obras provinciais, já que ficaram sob sua responsabilidade funções antes realizadas pelo diretor-geral. ${ }^{7}$ Ponto a destacar é que, a partir deste momento, passou-se a vincular a ocupação do cargo de engenheiro provincial com a posse de determinado corpus de conhecimento. Definiu-se que, para a contratação dos engenheiros, a sua capacidade profissional ${ }^{8}$ deveria ser avaliada pelo engenheiro chefe (LLM, Regulamento 53, art. 16, 1866).

Em 1870 implementou-se outra inovação administrativa - a divisão da província em sete distritos de obras públicas e ainda a criação de mais um cargo de engenheiro e também de sete ajudantes de engenheiros (LLM, lei 1688, 1870, p.78-79). Trata-se de aprimoramento da estrutura organizacional que representou importante descentralização administrativa, já que, potencialmente, permitiria dinamizar sua atuação por meio de engenheiros distritais. Outras novidades prosseguem na Seção Técnica no transcurso da década de 1870. O regulamento 68, publicado em 1873, reorganizou a diretoria, dando continuidade ao desenvolvimento de sua estrutura administrativa. Notadamente em relação aos engenheiros, alterações importantes ocorreram no quadro de funcionários e, sobretudo, no prestígio da categoria profissional. A designação do diretor-geral aparece como 'engenheiro diretorgeral', indicador de início de profissionalização do cargo e de ganho de prestígio político. Concomitantemente, previu-se a contratação de mais engenheiros, dois para os cargos de adjuntos do diretor-geral e outros sete como chefes distritais. Ao 'diretor-geral engenheiro' foram delegadas obrigações de correção dos projetos e trabalhos dos engenheiros subordinados e apresentação de mapa sinóptico, ao presidente da província, das obras em execução 
e executadas por contratos (LLM, Regulamento 68, 1873, p.1-7). Não houve mudanças nas atribuições dos engenheiros de distritos, mas aprimoramento na forma de atuação. Dando prosseguimento ao movimento de regulação do exercício profissional do engenheiro na esfera provincial deliberou-se que "os engenheiros que se propuserem a entrar para o quadro de pessoal técnico da diretoria de obras públicas, deverão provar com documentos legais que são bachareis em matemáticas ou que tem curso de engenharia em escolas acreditadas" (LLM, Regulamento 68, art. 38, 1873).

Essa legislação converge com as observações de Edmundo Campos Coelho sobre o pioneirismo do setor público em relação à regulação do exercício profissional do engenheiro (Coelho, 1999, p.199). A iniciativa certamente sofreu influência do fato de o Estado ser o principal destino dos egressos das escolas de engenharia no período imperial (Carvalho, 2002, p.103; Coelho, 1999, p.197).

Entretanto, concomitantemente à publicação da lei regulamentar 68, em 1873, publicouse a lei 2026 que aprovava o regulamento, mas que lhe imprimia alterações importantes. A mudança principal foi apresentada já no artigo primeiro. "A diretoria geral de obras públicas da província se comporá de um diretor geral, um secretário, dois primeiros oficiais, dois segundos ditos, um amanuense, um desenhista, um porteiro, um contínuo, um administrador de obras públicas. Farão parte da diretoria oito engenheiros, sendo um residente na capital, e sete chefes de distrito, e um adjunto" (LLM, lei 2026, art. 1o, 1873).

Um diretor-geral engenheiro passou a figurar não mais como obrigatoriedade, mas somente como possibilidade, como complemento foi criado o lugar de engenheiro residente que cuidaria dos assuntos de caráter técnico (LLM, lei 2026, art. 3o, 1873). As modificações se estenderam a outros cargos, como a supressão dos lugares dos diretores adjuntos, originalmente reservados a outros engenheiros.

Em meados da década de 1870, a legislação que cuidava do orçamento provincial impôs, do mesmo modo, alterações à diretoria. São observados avanços na estrutura organizacional, nas técnicas administrativas e nas formas de ação da repartição. Especificamente sobre os engenheiros, permaneceram as responsabilidades dos engenheiros distritais com a novidade de que, a partir de então, estavam proibidos de acumular cargos (LLM, Regulamento 78, art. $\left.8^{\circ}, 1876\right)$.

É necessário minudenciar as regras estabelecidas na lei regulamentar para elaboração dos planos e orçamentos das obras, que pretendiam aumentar o rigor técnico das construções. No plano deveriam constar descrição minuciosa da obra e as dimensões exatas de todas as partes que a compunham. No orçamento deveriam constar a tabela dos preços dos materiais conforme o custo corrente no respectivo distrito, da mão de obra e o tempo de duração das intervenções (LLM, Regulamento 78, art. 31-33, 1876). Do mesmo modo detalharam-se regras para elaboração dos projetos de obras de conservação. Mesmo com o interregno anterior, houve prosseguimento da profissionalização do cargo de diretor de obras públicas, pois um dispositivo alertava que:

Só poderá ser nomeado diretor geral das obras públicas os engenheiros ou bachareis pela escola central ou politécnica, ou que tiverem o curso da antiga escola militar (art. 88).

Só interinamente e na falta daqueles poderão ser nomeados os que tiverem títulos de escola estrangeira acreditada e mais de dois anos de prática civil na província (art. 89). 
Nos anos seguintes, novas leis deram continuidade ao processo de modernização das técnicas construtivas, estabelecendo itens que deveriam constar nos projetos, como 'desenho' e 'memória' ${ }^{\text {' }}$, indicadores que revelam aumento das exigências técnicas e, consequentemente, da qualidade dos projetos. Outra inovação a ser destacada é a discriminação de quais obras seriam realizadas por administração, empresa e arrematação. A partir de então, as edificações que, pela sua natureza, não pudessem ser orçadas com exatidão, aquelas que não pudessem ser confiadas a arrematantes e aquelas para as quais não fossem encontrados proponentes idôneos em duas praças consecutivas, seriam executadas por administração (a cargo de engenheiros). Por empresa seriam executadas as obras em que coubesse o estabelecimento de privilégio na forma da lei em vigor. Por fim, por meio da 'empreitada', seriam executadas todas as obras não compreendidas nas formas anteriores (LLM, Regulamento 87, art. 31, 1879).

O regulamento 101, de 1883, mais uma vez reestruturou a diretoria, como previsto no art. $4^{\circ}$ da lei 2892. A reforma representou continuidade com a modernização iniciada nas décadas anteriores, ao agregar novas atribuições e frentes de atuação da agência. Outros atores passaram a integrar o corpo de funcionários, uma vez que a reforma subordinou os engenheiros fiscais de estradas de ferro e de engenhos centrais, de navegação subvencionada, de iluminação pública e em geral de todas as empresas para as quais a província concorresse com subvenções, à Diretoria de Obras Públicas (LLM, Regulamento 101, art. 1o, 1883). Dentro da mesma tendência, designou ao diretor a obrigação de rever o processo de contas de empresas que tivessem de receber da província garantia de juros, subvenção quilométrica ou outros auxílios financeiros. Reafirmou por fim que, para os cargos de diretor geral e de engenheiros de distrito só poderiam ser nomeados indivíduos que tivessem título de engenheiro civil ou de minas pelas faculdades do Império (LLM, Regulamento 101, art. 125, 1883). Essa regra, claramente, tenta estabelecer uma espécie de reserva de mercado, nos termos propostos por Freidson (1994, p.145), para os engenheiros nacionais.

No capítulo do regulamento dedicado à organização dos projetos e orçamentos destacase o realce conferido aos componentes técnicos. É exigido o uso de cálculos matemáticos que possam servir de base para futuras avaliações das obras. Para tanto, os cálculos são expostos em quadros, com a devida especificação da fórmula que deveria ser empregada quando se tratasse de aterros ou escavações. As escalas para as plantas e desenhos foram determinadas no artigo 27. Além disso, todas as medidas deveriam ser expressas em unidades do sistema métrico, as de ângulos dadas pela graduação sexagesimal e as tintas das aquarelas deveriam ser as convencionadas, devidamente especificadas em tabela anexa. Se constatada a necessidade de alteração dos projetos, os substitutos deveriam seguir as mesmas regras (LLM, Regulamento 101, art. 22-34, 1883). Portanto, foram consignadas especificidades técnicas reveladoras de expressiva modernização da rotina construtiva e, principalmente, de aumento de exigência, por parte do setor público, da qualidade das obras que estavam sob sua responsabilidade. O esforço por parte da administração regional em normalizar vários aspectos técnicos é coevo à importante iniciativa nacional em construir um Vocabulário técnico de engenharia, no ano de 1876 (Telles, 1993, p.77). Embora não seja possível estabelecer eventuais ligações entre os dois movimentos, é importante assinalar sua concomitância. 
As duas últimas reformas administrativas do período imperial trataram do trabalho dos engenheiros fiscais das estradas de ferro e de alterações na divisão dos distritos de obras públicas. Das duas, a que deve ser destacada é a direcionada aos engenheiros das empresas ferroviárias. Ela representou tentativa tímida de controle, por parte da província, da expansão das estradas de ferro, já que buscou fiscalizar as próprias empresas por meio da atuação dos engenheiros. O regulamento determinou como necessária a manutenção, por toda companhia, de um engenheiro fiscal. Engenheiros, ressalte-se, que atuariam devidamente subordinados à Diretoria Geral das Obras Públicas (LLM, Regulamento 104, parágrafos 1ํ-ㅜㅜ 1884). Para ocupar o posto de engenheiro fiscal, reeditou-se tentativa de estabelecimento de reserva de mercado, ao definir que o postulante deveria ser engenheiro civil graduado pela Escola Politécnica do Rio de Janeiro ou engenheiro de minas com especialização em estrada de ferro $^{10}$ (LLM, Regulamento 104, art. 7ํ, 1884). Quando a estrada a fiscalizar excedesse $600 \mathrm{~km}$ em estudos e construção, poderia o engenheiro fiscal contar com ajudantes, que também deveriam ser engenheiros (LLM, Regulamento 104, art. 8, 1884).

Se mesclam a história da Diretoria de Obras Públicas da província e a história da atuação dos engenheiros no século XIX em Minas Gerais. Como demonstra a legislação exposta e analisada, a nova estrutura administrativa voltada para as obras públicas não ficou imune à presença dos engenheiros. A atuação desses profissionais, apesar dos fluxos e refluxos, incrementou-se no transcurso do século XIX e refletiu-se no regular desenvolvimento dos aspectos técnicos das construções, bem como no ganho de prestígio social por parte do engenheiro.

\section{Projetos, plantas, orçamentos e pareceres: dados para a reconstituição da atuação dos engenheiros provinciais de Minas Gerais}

Em levantamento realizado no Arquivo Público Mineiro foram localizadas 53 caixas com "Processos de construção de estradas e pontes", das quais 27 referem-se a estradas e 26 a pontes. É importante destacar que este corpus corresponde a conjunto remanescente sobre o qual é impossível determinar quanto do total gerado chegou aos dias atuais. Pelas mencionadas características da documentação, entende-se que tratamento estatístico tanto possibilitará a construção de perfil geral, quanto facultará necessária avaliação da cobertura e representatividade dos dados, indispensável ao estabelecimento do potencial e limites dos processos.

Na sequência são apresentados resultados da codificação de uma das 27 caixas (caixa 2) dos "Processos de construção de estradas". A intenção é apresentar o perfil geral do acervo. ${ }^{11}$ No Quadro 1 estão relacionadas as obras públicas da caixa 2. Ele permite a visualização de todas as referências às obras públicas realizadas, com largo predomínio das viárias, especificamente estradas e pontes. É importante observar que a discriminação dos locais de intervenção sugere prática administrativa de segmentar uma mesma obra viária em várias seções. Também é importante anotar que a estrita localização das intervenções é tarefa que requer profundo conhecimento da geografia da província de Minas Gerais, pela minudência em discriminar 'lugares', pequenos acidentes geográficos e obras de arte específicas, sobretudo pontes. 
Quadro 1: Relação das obras públicas referentes à documentação da caixa 2 dos "Processos de construção de estradas", Minas Gerais, 1848-1887

Bueiro: córrego Aguenta Sol

Cadeia e casa de câmara: Formiga

Capela: em Passagem

Estrada: Água Santa a ponte do Rio do Peixe

Estrada: Águas de Lambari a Contendas

Estrada: Águas Virtuosas a Campanha

Estrada: Aimorés a Teófilo Otoni

Estrada: Aiuruoca a Bocaiúva

Estrada: Aiuruoca a Passa Vinte

Estrada: Aiuruoca a Rio Grande

Estrada: Aiuruoca a Rio Preto

Estrada: Alfenas

Estrada: arraial da Onça e o lugar Duas Pontes Estrada: Cabo d'Agosta a Santa Bárbara Estrada: Camargos a Bento Rodrigues e deste para Inficionado

Estrada: Campanha as Águas Virtuosas e ao Rio de Janeiro

Estrada: Catas Altas

Estrada: da Vargem Grande pela Palmella

dos Coelhos

Estrada: de Anta a Abre-Campo

Estrada: de Antônio Pereira

Estrada: de Araxá

Estrada: desde o córrego de São Gabriel até a Ponte do Empossado

Estrada: do Paraibuna, entre D. Anna e o Engenho Estrada: Formiga a Oliveira

Estrada: Inficionado ao arraial D'água Quente Estrada: Itabira a Itambé (Campestre a Fábrica do Girão)

Estrada: Jaguari a Santa Rita

Estrada: Passa Quatro a província de São Paulo

Estrada: porta do Barros (negociante Cocaes) a alto da Serra (lugar Cavaco)

Estrada: Porto Velho do Cunha

Estrada: Rio Doce

Estrada: Santa Bárbara a Catas Altas
Estrada: Santa Bárbara a Cocais

Estrada: Santa Bárbara a encruzilhada da estrada antiga do Bitancourt

Estrada: Santa Bárbara a Itabira (Alto Capoeirão ao Rio do Peixe)

Estrada: Santa Bárbara a Itabira (Alto do Morro do Vieira a Ponte dos Gralhos)

Estrada: Santa Bárbara a Itabira (Ponte dos Gralhos a São Gonçalo do Rio Abaixo)

Estrada: Santa Bárbara a Itabira (rancho Bernardino C. Lage nas Baleias a Alto Capoeirão)

Estrada: Santa Bárbara a Itabira (rancho Bernardino C. Lage nas Baleias a São Gonçalo do Rio Abaixo) Estrada: Serro

Estrada: Serro ao Porto de Sousa

Estrada: Serro: córrego de São Francisco (entre Morro d'Água Quente e Catas Altas)

Estrada: Serro: entre o arraial da Onça e ponte sobre o Córrego da Vargem

Estrada: Serro: entre ponte do Rio das Pedras a Fábrica do Eduardo

Estrada: Serro: Itambé ao Onça

Estrada: Serro: ponte da Vargem e as Duas Pontes Estrada: Serro: ponte do Itambé a ponte do Rio do Peixe

Ferrovia: Companhia Estrada de Ferro Leopoldina

Ponte: córrego da Cata Preta

Ponte: em Conceição

Ponte: na Estrada do Inficionado ao Morro

D’Água Quente

Ponte: ribeirão de Camargos

Ponte: Rio de São Francisco (próxima a Santa Bárbara)

Ponte: Rio Itajubá na estrada do Serro

Ponte: Rio Piracicaba em Inficionado

Ponte: Rio Santa Bárbara no lugar

denominado Vieira

Ponte: sobre o Rio Cabo Verde

Ponte: sobre o Rio Onça

Pontes: Catas Altas do Mato Dentro, córrego Praia Preta e Água Quente

Pontes: córrego de São Francisco e córrego de Paracatu

Pontes: córregos do Catinga e Bento Ferraz

Pontes: rancho de Antônio Reis e ponte casa de Joaquim Rosa ou córrego de Taperas

Pontes: sobre o córrego dos Pinheiros e ponte do córrego de Manoel Antônio

Pontes: sobre os ribeirões de São Gabriel e Funil

Fonte: PCE 
Os resultados para a variável que contabilizou o local de elaboração dos documentos ('circunscrição', 'instância') revelou questão importante da dinâmica de edificação e manutenção da rede viária pública de Minas Gerais, ou seja, o fato de procederem do governo provincial os recursos que financiavam as obras registradas nos processos. Esta constatação está demonstrada na Tabela 1, especificamente a concentração da origem dos documentos em Ouro Preto, visto que quase dois terços de toda a documentação foi elaborada na então capital de Minas Gerais. No período, à dimensão provincial das intervenções na rede viária, fartamente documentada pelos processos, somava-se a dimensão municipal, ou aquela sob a responsabilidade das câmaras, e a dimensão imperial, ou as intervenções determinadas e/ou realizadas pelo governo central. Entretanto, essas duas dimensões (municipal e imperial) não estão documentadas nos processos. No transcurso do período imperial foi forjada, progressivamente, a divisão de atribuições entre as três esferas de poder, no que concerne aos transportes. Assim, a promoção da navegação e a construção das estradas interprovinciais estavam subordinadas ao governo central, mesmo que os governos provinciais e municipais participassem do financiamento, da administração e da execução de intervenções nessas modalidades (Brasil, 29 ago. 1828). No caso de Minas Gerais, constatouse, por meio do estudo das finanças provinciais e municipais (Barbosa, 2009), que a manutenção e expansão da rede viária terrestre (estradas e pontes) realizou-se segundo a combinação de recursos dessas duas esferas de poder, inclusive com repartição variável do gasto público ao longo do século.

A procedência da correspondência dessa caixa ilumina aspectos significativos da dinâmica do processo de intervenção provincial: número menor de municípios responde por parte maior da documentação e, provavelmente, das obras. Coloca-se também a possibilidade de reconstruir o perfil da distribuição regional das obras provinciais, que permitiria conhecer quais localidades conseguiram, ao longo do período imperial, angariar maior número de intervenções.

Como a data é uma variável já tabulada, foi possível quantificar integralmente todas as datas dos documentos referentes aos "Processos de construção de estradas". Ela revelou a distribuição, no tempo, da documentação das obras viárias em Minas Gerais.

Tabela 1: Distribuição das localidades de origem da documentação da caixa 2 dos "Processos de construção de estradas", Minas Gerais, 1848-1887*

\begin{tabular}{|c|c|c|c|c|c|}
\hline \multirow[t]{2}{*}{ Origem dos documentos } & \multicolumn{2}{|c|}{ A) Localidade } & \multicolumn{2}{|c|}{ B) Documento } & \multirow{2}{*}{$\begin{array}{c}\text { Média } \\
\text { (B/A) }\end{array}$} \\
\hline & $\mathbf{n}^{\circ}$ & $\%$ & $n^{\circ}$ & $\%$ & \\
\hline Ouro Preto & 1 & 2,3 & 210 & 56,3 & - \\
\hline $\begin{array}{l}\text { Localidades com quatro } \\
\text { documentos ou mais ( } 1 \% \text { ou mais) })^{* *}\end{array}$ & 15 & 34,1 & 117 & 31,4 & 7,8 \\
\hline $\begin{array}{l}\text { Localidades com menos de quatro } \\
\text { documentos (menos de } 1 \% \text { ) }\end{array}$ & 28 & 63,6 & 46 & 12,3 & 1,6 \\
\hline Total & 44 & 100 & 373 & 100 & - \\
\hline
\end{tabular}

* Excluídos 31 documentos sem identificação da localidade de origem. **Localidades com quatro documentos ou mais: Aiuruoca, Antônio Pereira, Araxá, Cabo Verde, Campanha, Catas Altas, Cocais, Conceição, Inficionado, Itabira, Itambé do Mato Dentro, Rio de Janeiro, Santa Bárbara, São Gonçalo do Rio Abaixo e São João del-Rei. Fonte: PCE 
A Tabela 2 traz a distribuição quinquenal e decenal dos documentos, e o Gráfico 1 ilustra a evolução quinquenal. Os dados da tabela mostram crescimento da produção de documentação a indicar provável maior número de intervenções, com concentração na década de 1850, seguida de queda no decênio seguinte. Após esta mudança na tendência, novamente há recuperação do crescimento, mas em níveis mais baixos. O número crescente certamente resulta de no mínimo duas determinantes. A primeira decorrente da maior estruturação do aparato estatal, sobretudo da repartição de obras públicas provinciais, e a segunda, do dinamismo da economia a exigir constante ampliação das vias terrestres de transporte.

Tabela 2: Distribuição quinquenal e decenal dos documentos dos "Processos de construção de estradas", Minas Gerais, 1840-1889*

\begin{tabular}{lrrrrr}
\hline Quinquênio & \multicolumn{2}{c}{ Documentos } & \multicolumn{2}{c}{ Decênio } & \multicolumn{2}{c}{ Documentos } \\
\hline & \multicolumn{1}{c}{$\mathbf{n}^{\circ}$} & \multicolumn{1}{c}{$\%$} & & $\mathbf{n} \mathbf{n}^{\circ}$ & $\%$ \\
\cline { 2 - 7 } $1840-1844$ & 70 & 0,8 & $1840-1849$ & 186 & 2,2 \\
$1845-1849$ & 116 & 1,3 & & & \\
$1850-1854$ & 838 & 9,7 & $1850-1859$ & 2.544 & 29,5 \\
$1855-1859$ & 1.706 & 19,8 & & & \\
$1860-1864$ & 1.014 & 11,8 & $1860-1869$ & 1.672 & 19,4 \\
$1865-1869$ & 658 & 7,6 & & & \\
$1870-1874$ & 1.223 & 14,2 & $1870-1879$ & 2.097 & 24,3 \\
$1875-1879$ & 874 & 10,1 & & & \\
$1880-1884$ & 1.116 & 12,9 & $1880-1889$ & 2.120 & 24,6 \\
$1885-1889$ & 1.004 & 11,6 & & & \\
\hline Total & $\mathbf{8 . 6 1 9}$ & $\mathbf{1 0 0}$ & Total & $\mathbf{8 . 6 1 9}$ & $\mathbf{1 0 0}$ \\
\hline
\end{tabular}

* Excluídos 361 casos cujas datas não são informadas. Fonte: PCE

Gráfico 1: Distribuição quinquenal dos documentos dos "Processos de construção de estradas", Minas Gerais, 1840-1889

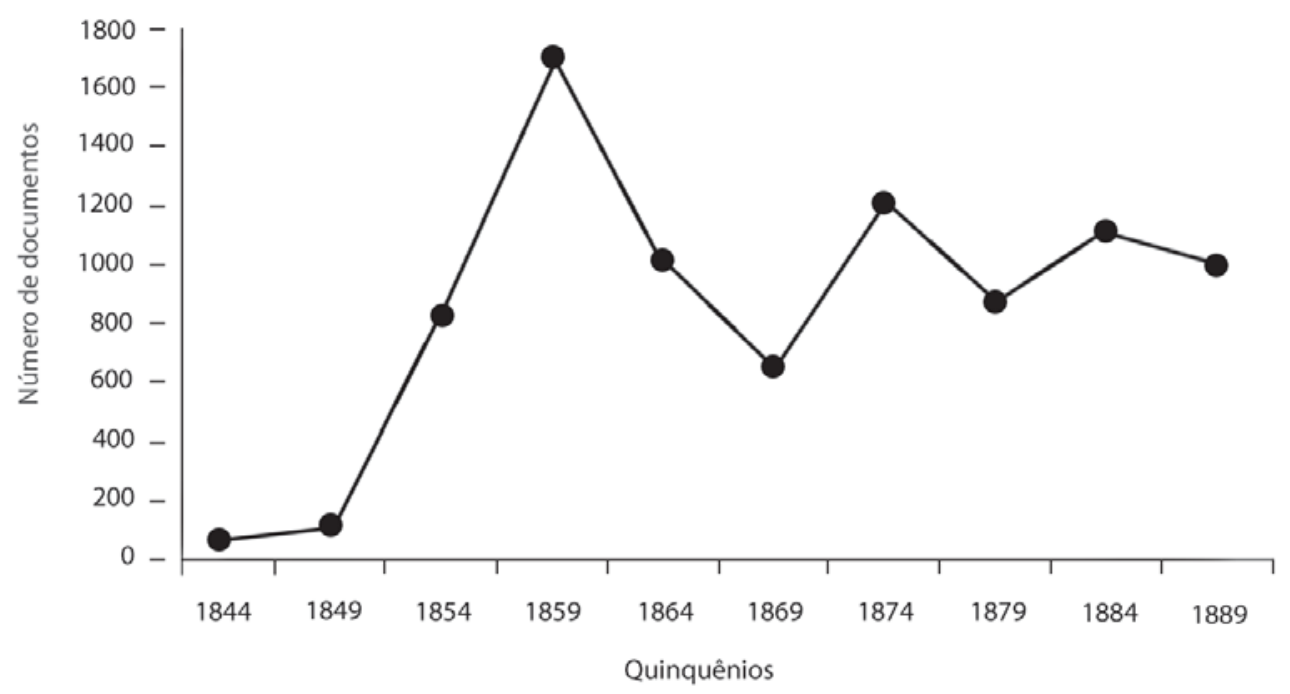


As duas variáveis que tratam da origem e do destino da documentação ('autoria', 'destinatário') também evidenciam questões significativas da dinâmica de edificação e manutenção da infraestrutura de transportes viários em Minas Gerais. A primeira característica diz respeito às várias agências e agentes envolvidos na edificação e conservação das vias terrestres. Sobressai a expressiva participação dos engenheiros provinciais, presentes na administração desde a segunda metade da década de 1830. As variáveis desvendam organograma ampliado das obras públicas viárias, muito mais completo do que o obtido por meio da legislação provincial, discutida no tópico anterior. Estavam envolvidos não só os vários funcionários da Diretoria de Obras Públicas e o presidente de província, mas também os engenheiros, câmaras, a Mesa de Rendas Provincial e agentes que estavam fora do setor público, como os arrematantes, conservadores, empreiteiros, concessionários e procuradores de arrematantes.

No Quadro 2 estão detalhada toda a instituições, cargos e funções dos autores e destinatários da documentação da caixa 2, seguido de duas tabelas em que foram agregados destinatários e autores. Para os engenheiros, além de identificar o aparecimento da função, também são registrados seus respectivos nomes.

Quadro 2: Instituições, cargos e funções dos autores e destinatários da documentação da caixa 2 dos "Processos de construção de estradas", Minas Gerais, 1848-1887

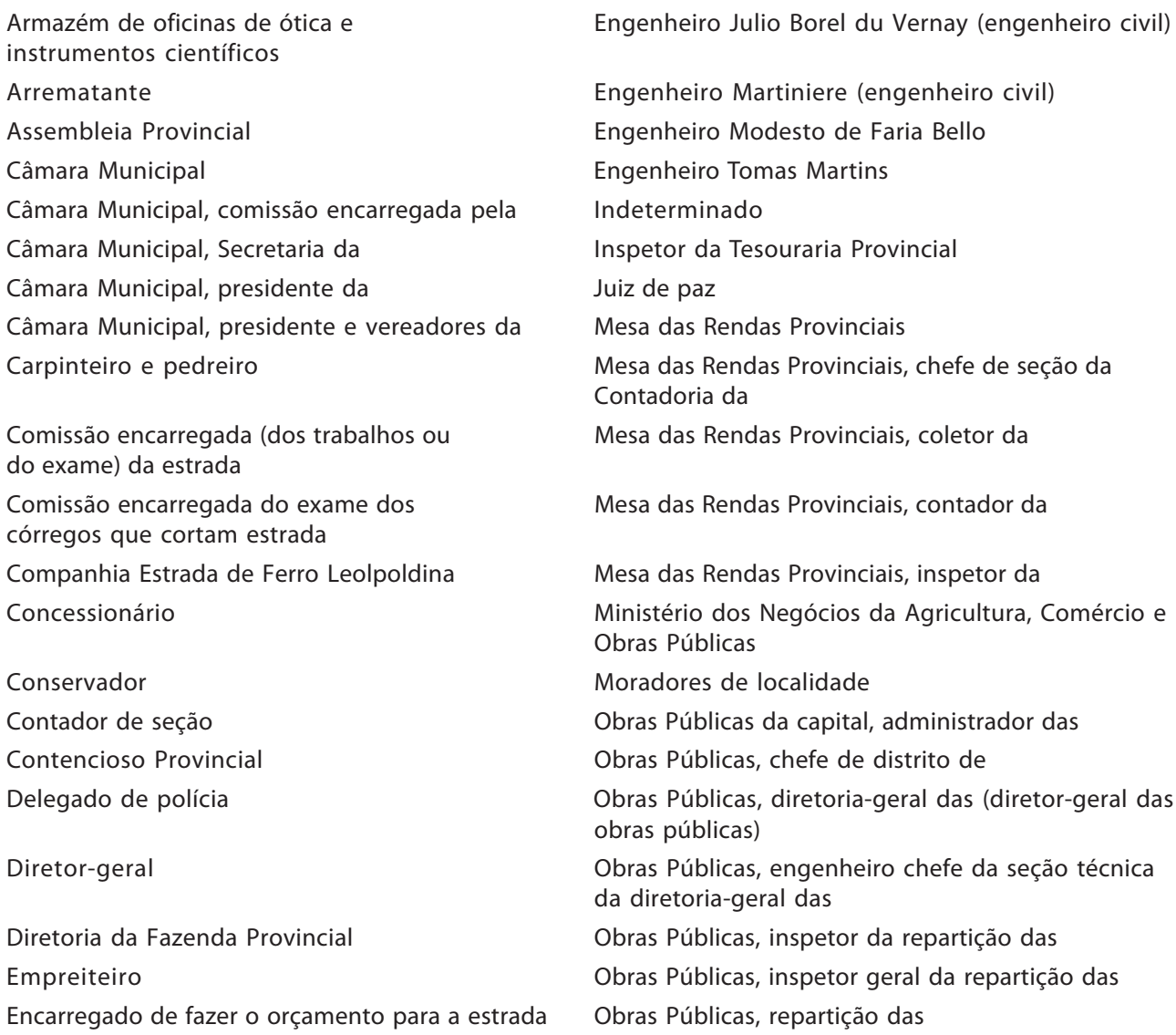


Quadro 2: Instituições, cargos e funções dos autores e destinatários da documentação da caixa 2 dos "Processos de construção de estradas", Minas Gerais, 1848-1887 (cont.)

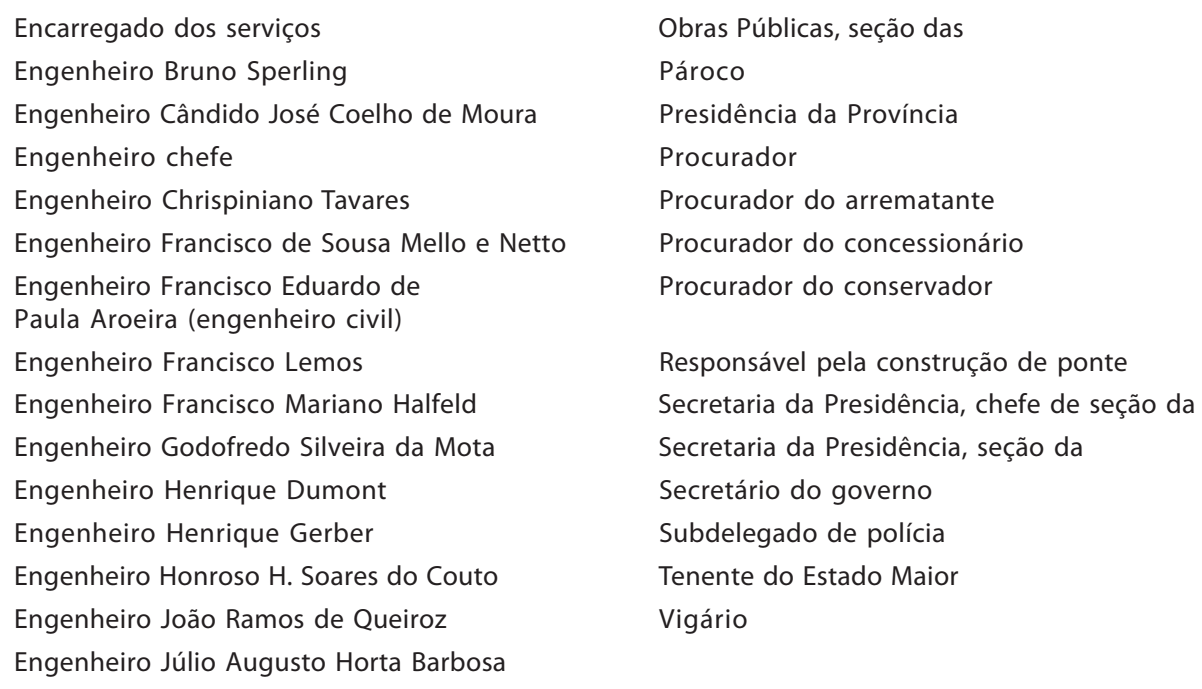

A autoria dos documentos revela os principais envolvidos com as obras públicas viárias: os engenheiros provinciais, os executores das obras (arrematantes, concessionários, conservadores e empreiteiros) e as câmaras municipais. Os três grupos somados perfaziam a maior parte das missivas, ou quase dois terços da autoria da correspondência (63,9\%). Ponto a destacar é a majoritária participação dos engenheiros provinciais (25,2\%) a sinalizar atuação significativa na construção de estradas e pontes. Como ressaltado em tópico anterior, a presença de engenheiros na construção de estradas e pontes será crescente no transcurso do século XIX, concomitante com a crescente complexidade de suas atribuições e campo de atuação. Alcança-se o ápice da presença de engenheiros no setor público no pós-1860, quando passam a ocupar também o cargo de diretor de Obras Públicas. Trata-se, portanto, de importante capítulo da história de l'engénieur au service d'Etat (Shinn, 1978, p.40) em Minas Gerais.

Tabela 3: Classificação da autoria dos documentos da caixa 2 dos "Processos de construção de estradas", Minas Gerais, 1848-1887*

\begin{tabular}{|c|c|c|}
\hline \multirow[t]{2}{*}{ Autoria } & \multicolumn{2}{|c|}{ Documentos } \\
\hline & $\mathbf{n}^{\circ}$ & $\%$ \\
\hline Engenheiros da província & 84 & 25,2 \\
\hline $\begin{array}{l}\text { Arrematante, concessionário, conservador, empreiteiro; procurador de arrematante, } \\
\text { de concessionário, de conservador }\end{array}$ & 65 & 19,5 \\
\hline $\begin{array}{l}\text { Câmara Municipal; autoridades locais: subdelegado de polícia, juiz de paz, } \\
\text { vigário, pároco }\end{array}$ & 64 & 19,2 \\
\hline Diretoria Geral das Obras Públicas & 55 & 16,5 \\
\hline Mesa das Rendas Provinciais; Tesouraria Provincial; Fazenda Provincial & 36 & 10,8 \\
\hline Presidência da Província; Secretaria da Presidência & 29 & 8,7 \\
\hline Total & 333 & 100 \\
\hline
\end{tabular}

* Excluídos 45 casos $(11,1 \%)$ de documentos sem informação de autoria ou de autoria indeterminada e $26(6,4 \%)$ casos de documentos de outras autorias.

Fonte:PCE 
Já o perfil dos destinatários destaca a ostensiva presença da Presidência da Província (62\%). Assim, se os arrematantes e engenheiros executavam as obras, o presidente da província tomava as decisões. Nessa medida, impõe-se lembrar o papel desempenhado pelos governos provinciais como um dos principais mecanismos do poder centralizador, que partia da sede imperial da monarquia constitucional brasileira (Gouvêa, 2008, p.19). Somados os percentuais relativos à Presidência da Província, Diretoria Geral de Obras Públicas, Mesa das Rendas Provinciais e Tesouraria Provincial, constata-se quadro de elevada centralização administrativa, ou seja, mais de $90 \%$ da documentação se dirigiu a esses órgãos.

Tabela 4: Classificação do destinatário dos documentos da caixa 2 dos "Processos de construção de estradas", Minas Gerais, 1848-1887*

\begin{tabular}{|c|c|c|}
\hline \multirow[t]{2}{*}{ Destinatário } & \multicolumn{2}{|c|}{ Documentos } \\
\hline & no & $\%$ \\
\hline Presidência da Província & 178 & 62,0 \\
\hline Diretoria Geral das Obras Públicas & 76 & 26,5 \\
\hline Câmara Municipal, autoridades locais (subdelegado e delegado de polícia, juiz de paz) & 16 & 5,6 \\
\hline Engenheiros da província & 8 & 2,8 \\
\hline Mesa das Rendas Provinciais, Tesouraria Provincial & 6 & 2,1 \\
\hline Arrematante & 3 & 1,0 \\
\hline Total & 287 & 100 \\
\hline
\end{tabular}

* Excluídos 117 casos (28,9\%) de documentos sem informação de autoria ou de autoria indeterminada. Fonte: PCE

O Quadro 3 e a Tabela 5, com o temário e classificação temática dos documentos da caixa 2, revelam que os engenheiros foram ativos no cumprimento das funções que lhes foram estabelecidas pela legislação. $\mathrm{O}$ que se consubstanciou em registros importantes para o conhecimento das técnicas construtivas utilizadas nas obras viárias mineiras do século XIX.

Quadro 3: Temário da documentação da caixa 2 dos"Processos de construção de estradas", Minas Gerais, 1848-1887

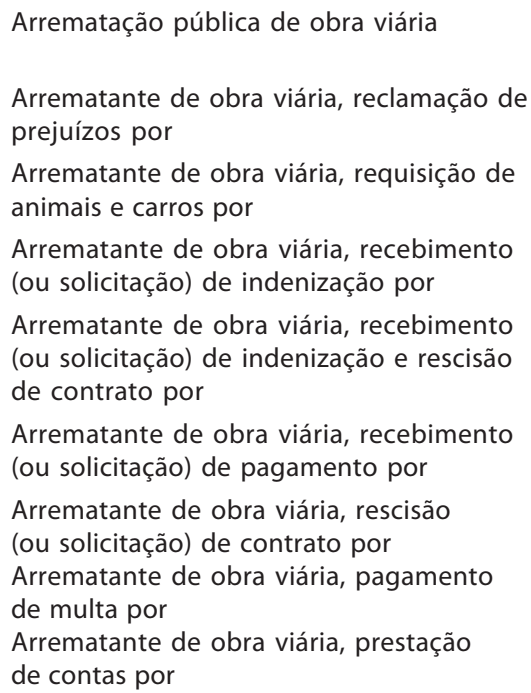

Engenheiro sobre obra viária, parecer de (ou solicitação de parecer de)

Engenheiro: despesas com obras viárias

Ferrovia: informe sobre 'garantias' do Governo Provincial

Ferrovia: informe sobre andamento da construção de estrada de ferro

Indenização a proprietário por propriedade atravessada por obra viária

Liberação de recursos públicos para obra viária

Orçamento e planta de obra viária

Orçamento de obra viária

Orçamento de obra viária, insuficiência do 
Quadro 3: Temário da documentação da caixa 2 dos"Processos de construção de estradas", Minas Gerais, 1848-1887 (cont.)

\begin{tabular}{|c|c|}
\hline $\begin{array}{l}\text { Arrematante de obra viária, informação sobre } \\
\text { andamento/conclusão de obra por }\end{array}$ & $\begin{array}{l}\text { Orçamento de obra viária, solicitação de } \\
\text { elaboração de }\end{array}$ \\
\hline $\begin{array}{l}\text { Arrematante de obra viária, transferência de } \\
\text { obra para o Governo Provincial por }\end{array}$ & $\begin{array}{l}\text { Orçamento: solicitação de esclarecimento do } \\
\text { Governo Provincial a arrematante }\end{array}$ \\
\hline $\begin{array}{l}\text { Arrematante de obra viária, solicitação de } \\
\text { parecer (de engenheiro) sobre obra por }\end{array}$ & Outras obras: cadeia e casa de câmara \\
\hline $\begin{array}{l}\text { Arrematante de obra viária, prorrogação } \\
\text { (ou solicitação de) prazo para conclusão de } \\
\text { obra por }\end{array}$ & Outras obras: capela \\
\hline Assuntos diversos em um mesmo documento & Outras obras: paiol \\
\hline Assuntos especiais & Outras obras: quartel \\
\hline $\begin{array}{l}\text { Assuntos não pertinentes a obras públicas } \\
\text { (ou renovação de contrato) }\end{array}$ & Pagamento de trabalhadores em obra viária \\
\hline Contrato (ou arrematação) de obra viária & Parecer de autoridade local sobre obra viária \\
\hline $\begin{array}{l}\text { Cooperação de Câmara Municipal e } \\
\text { Governo Provincial em obra viária }\end{array}$ & Parecer sobre a necessidade de obra viária \\
\hline Custos de equipamentos para obra viária & Parecer sobre obra viária \\
\hline $\begin{array}{l}\text { Desapropriação de terras atravessadas } \\
\text { por obra viária }\end{array}$ & Planta de estrada \\
\hline $\begin{array}{l}\text { Despesas com obra viária } \\
\text { repartição de obras públicas }\end{array}$ & Planta de ponte \\
\hline Documentação de caráter interno a & $\begin{array}{l}\text { Projeto e orçamento de obra viária, } \\
\text { (solicitação de elaboração de) }\end{array}$ \\
\hline $\begin{array}{l}\text { Engenheiro e comissão para obra viária, } \\
\text { nomeação de }\end{array}$ & Projeto e planta de obra viária \\
\hline $\begin{array}{l}\text { Engenheiro para obra viária (ou para distrito } \\
\text { de obras viárias), nomeação de }\end{array}$ & Projeto de obra viária, (solicitação de elaboração de) \\
\hline $\begin{array}{l}\text { Engenheiro, requisição de equipamentos } \\
\text { para obra viária por }\end{array}$ & Projeto de obra viária, discussão sobre \\
\hline $\begin{array}{l}\text { Engenheiro, requisição de trabalhadores } \\
\text { para obra viária por }\end{array}$ & $\begin{array}{l}\text { Solicitação de obra viária por meio de } \\
\text { representação/abaixo-assinado }\end{array}$ \\
\hline
\end{tabular}

Fonte: PCE

A Tabela 5 possibilita avaliar o peso relativo dos temas. Nota-se que a documentação que certamente estava sob a responsabilidade direta dos engenheiros provinciais, como projetos, plantas, orçamentos e pareceres, tem peso significativo, representa mais de um terço dos documentos $(34,1 \%)$.

Realizadas a sistematização e codificação de aproximadamente um terço dos documentos dos "Processos de construção de estradas e pontes", algo em torno de 7.500 documentos, foi identificada mais de meia centena de engenheiros que passaram pela repartição de obras públicas. Alguns com longeva atuação, como Modesto Faria Bello e Bruno von Sperling, que se aposentaram como funcionários provinciais (LLM, leis 3321 e 3439). Outros com prováveis breves passagens, como João Ramos de Queiroz e Luiz Guilherme Dodt, sobre os quais remanesceu escassa documentação. Dos nomes mais recorrentes ou daqueles sobre os quais remanesceu maior volume de documentos destacam-se: Antônio Olinto de Almeida Gomes, Bruno Von Sperling, Cândido Jose Coelho de Moura, Fernando Halfeld $^{12}$, Francisco Eduardo de Paula Aroeira, Henrique Dumont, Henrique Gerber, Honório 
H. Soares do Couto, João José da Silva Teodoro, Joaquim Francisco de Paula, Julio Borel du Vernay e Modesto de Faria Bello.

Por fim, alguns elementos biográficos de três dos engenheiros com maior volume de documentação revelam como a experiência profissional em Minas Gerais marcou suas trajetórias de vida e resultou em relevantes contribuições para a história da categoria profissional no Brasil.

$\mathrm{O}$ engenheiro de minas Joaquim Francisco de Paula atuou em várias atividades na província e depois estado de Minas Gerais. Nasceu em 1857, em Barbalha (CE), realizou os estudos de engenharia de minas na Escola Politécnica do Rio de Janeiro e na Escola de Minas de Ouro Preto. São inúmeros os documentos produzidos por Joaquim Francisco quando exercia a função de engenheiro provincial. Foi um dos fundadores da Escola de Engenharia da Universidade de Minas Gerais, da qual foi professor. Pioneiro na extração de manganês, descobriu também minerais atômicos no estado de Minas Gerais. Foi representante oficial de Minas Gerais na Exposição Nacional de 1908, realizada no Rio de Janeiro, quando foi divulgado estudo sobre as riquezas minerais do estado que, posteriormente, alcançaria grande repercussão no âmbito internacional. Desempenhou as funções de diretor-geral das obras de melhoramento da capital, além de ter chefiado as obras de desobstrução do rio das Velhas e do rio São Francisco. Teve ainda atuação política notável, sobretudo por seus ideais republicanos, tendo sido um dos fundadores do Partido Republicano Mineiro e participado ativamente da Revolta da Armada. Recebeu comendas e condecorações de países estrangeiros por seus importantes trabalhos. Morreu em Belo Horizonte em 1924 (Rivera, 1971; Santos, 2009; PCE).

Tabela 5: Classificação temática dos documentos da caixa 2 dos "Processos de construção de estradas", Minas Gerais, 1848-1887

\begin{tabular}{|c|c|c|}
\hline \multirow[t]{2}{*}{ Temário } & \multicolumn{2}{|c|}{ Documentos } \\
\hline & $\mathrm{n}^{0}$ & $\%$ \\
\hline $\begin{array}{l}\text { Arrematação de obras viárias (amplo temário, sobretudo contratação, execução } \\
\text { e pagamento) }\end{array}$ & 103 & 25,8 \\
\hline Projetos, plantas e orçamentos (solicitação, discussão, elaboração, documentos técnicos) & 81 & 20,3 \\
\hline $\begin{array}{l}\text { Parecer sobre obra viária (provavelmente sem autoridade técnica, sobretudo } \\
\text { autoridades locais) }\end{array}$ & 69 & 17,3 \\
\hline Pareceres de engenheiros (designação, solicitação e documentos técnicos) & 55 & 13,8 \\
\hline Despesas diversas (equipamentos, desapropriações, indenizações, pagamento trabalhadores) & 33 & 8,3 \\
\hline Outros temas (outras modalidades viárias, obras públicas não viárias, assuntos diversos) & 32 & 8,0 \\
\hline Contrato de obra viária (provavelmente arrematação nova ou renovação) & 26 & 6,5 \\
\hline Total & 399 & 100 \\
\hline
\end{tabular}

* Excluídos cinco casos de assunto indeterminado.

Fonte: PCE

Henrique Gerber é outro engenheiro com destacada e longeva atuação em intervenções na rede viária mineira. Em dezembro de 1861, a província estabeleceu contrato com Gerber para "mandar litografar na Europa carta corográfica da província que ele organizou" (Martins, 1998, p.39), em substituição à carta desenhada por Halfeld-Wagner anos antes. O mapa foi publicado em 1863, acompanhado pelas "Noções geográficas e administrativas da província de Minas Gerais". Ainda como resultado de sua experiência em Minas Gerais, escreveu trabalhos importantes sobre aspectos geográficos da província, como: "Geographical 
notes on the province de Minas Geraes", publicado no Journal of the Royal Geographical Society de Londres. Foi também agraciado com o título de Cavaleiro da Ordem da Rosa (Blake, 1895; PCE, PCP).

Heinrich Wilhelm Ferdinand Halfeld nasceu em 23 de fevereiro de 1797 em Clausthal, reino de Hannover. Fez seus estudos de engenharia na Bergakademie Clausthal, a segunda mais antiga escola de minas da Alemanha. Mudou-se para o Brasil em 1825, como oficial mercenário do Corpo de Tropas Estrangeiras do Exército Imperial e estabeleceu-se inicialmente no Rio de Janeiro. Pouco tempo depois, deu baixa no Exército e dirigiu-se para Minas Gerais, onde foi empregado sucessivamente como engenheiro das companhias de mineração de São João Del-Rei (St. John del Rey Mining Company), Gongo Soco e Serra de Cocais, trabalhando na exploração de ouro até 1834 . Em 13 de maio de 1836 Halfeld assinou contrato com o Governo de Minas Gerais para exercer o cargo de engenheiro chefe da província e nesse exercício esteve 14 anos, durante os quais realizou muitos e importantes trabalhos, entre os quais a construção da Estrada do Paraibuna, uma das importantes vias de comunicação de Minas Gerais com o Rio de Janeiro. Em 1839, quando exercia a função de engenheiro provincial, naturalizou-se brasileiro e mudou seu nome para Henrique Guilherme Fernando Halfeld. Mais tarde, foi encarregado da exploração do rio São Francisco e seus afluentes desde a cachoeira de Pirapora até o Atlântico, por incumbência do governo imperial (Martins, 1998, p.31), pesquisa que realizou entre 1852 e 1854, e que resultou na publicação de monumental estudo: Atlas e relatório concernente a exploração do rio São Francisco. Explorou também o rio Grande. Foi ainda o construtor da estrada União e Indústria, a maior obra rodoviária da América do Sul na época (1861). Também exerceu cargos políticos e militares, dentre os quais o de tenente-coronel da Guarda Nacional. Prestou serviços relevantes na construção de meios de defesa para a capital de Minas Gerais, Ouro Preto, na época da Revolução Liberal de 1842. Atuou como sócio correspondente do Instituto Histórico e Geográfico Brasileiro. É o autor da Carta de Minas Gerais, de Die Brasilianische Provinz Minas Geraes, e da Planta do arraial de Santa Luzia e suas imediações. Em Juiz de Fora (Minas Gerais), ocupou vários cargos que demonstram o prestígio social e político que usufruiu, como o de juiz comissário da medição de terras públicas e de vereador da Câmara (1857-1868). Interrompeu a carreira de engenheiro para alistar-se no Exército anglo-prussiano, lutando na batalha de Waterloo contra Napoleão I, no posto de capitão. Faleceu na cidade de Juiz de Fora em novembro de 1873 (Veiga, 1998; Blake, 1895; Paula, 1974, Bastos, 1975).

\section{Considerações finais}

As informações consignadas nos "Processos de construção de estradas e pontes" ressaltam a necessidade de se voltarem os olhos para as vastas e regulares atividades de edificação e conservação de centenas de estradas e pontes que compuseram, provavelmente, a mais extensa e complexa malha viária do Brasil do século XIX. Atividades que contaram com atuação significativa de engenheiros, resultando em intervenções que, por não se localizarem em centros urbanos, como no caso dos templos religiosos, casas de câmara e cadeias públicas, acabaram por atrair pouca atenção dos pesquisadores. 
Em março de 1855, os habitantes de Santo Antônio do Calambau, pequeno distrito da Vila de Piranga, enviaram a seguinte carta ao presidente de província:

Os habitantes do Distrito de Santo Antônio do Calambau do município da Vila da Piranga, levam ao conhecimento de V. Exa. o miserável e perigoso estado em que se acha a ponte sobre o rio Piranga, construída neste arraial, sendo esta de suma necessidade, não só para o trânsito de [viajores] e tropas do caminho do Rio, e de outros lugares, como também para o uso dos habitantes que dela fazem para virem assistir os ofícios, e atos religiosos, e recorrem as necessidades dos Sacramentos, e sendo um bem público, e este Distrito em que muito concorre com direitos para a Fazenda Pública, pelo grande numero de fábricas de Engenho, e outros víveres: portanto levam ao conhecimento de V. Exa afim de estender suas vistas ordenando para que a dita Ponte seja observada por algum Engenheiro da Província, orçando este o que deve ser empregado no dito conserto (PCP, 1835).

Afora o caráter enfático da missiva, sobressai o fato de moradores de remota localidade mineira já conhecerem, em meados da década de 1850, a necessidade da presença de engenheiro e de seu respectivo aval técnico para se iniciar imprescindível intervenção na malha viária local. Exemplo que indiscutivelmente chama atenção para a importância de estudos que abordem a atuação dos engenheiros em Minas Gerais em fase anterior à fundação da Escola de Ouro Preto. Estudos necessários não apenas para o preenchimento de verdadeira lacuna historiográfica no quadro da história da categoria profissional no Brasil, mas que também contemplem campo de investigação essencial à compreensão de aspectos

\section{NOTAS}

* Este estudo integra pesquisa desenvolvida no doutorado do Programa de Pós-graduação em História Social da Universidade Federal do Rio de Janeiro e também a linha de pesquisa "Transportes em Minas Gerais, 1850-1930", coordenada pelo professor Marcelo M. Godoy, no âmbito do Núcleo de Pesquisa em História Econômica e Demográfica do Centro de Desenvolvimento e Planejamento Regional de Minas Gerais /Universidade Federal de Minas Gerais. O recolhimento de dados no Arquivo Público Mineiro foi realizado pelos bolsistas Télio Anísio Cravo e Philipe Sherrer Mendes, a quem a autora agradece.

${ }^{1}$ Neste texto, sob o grande guarda-chuva terminológico 'engenheiro' estão subentendidos os vários ramos da engenharia. Tal postura deriva da impossibilidade de diferenciar, na documentação compulsada, as especializações profissionais dos engenheiros que são objetos deste estudo.

${ }^{2}$ A bacia do São Francisco projeta-se para o interior do Nordeste; em sentido inverso, a bacia do Paraná direciona-se para o sul e integra-se ao Prata; as bacias do Jequitinhonha, Mucuri e Doce convergem para o litoral e conformam caminhos fluviais a possibilitar ligação com o exterior; a bacia do Paraíba do Sul serpenteia através de vales que medeiam as serras do Mar e da Mantiqueira, além de definir a maior parte da fronteira com o Rio de Janeiro.

${ }^{3}$ A navegação fluvial foi pensada como forma de resolver o problema dos transportes em Minas Gerais, conquanto de forma figurativa, se comparada com as outras modalidades (Iglesias, 1958, p.168).

${ }^{4}$ Adota-se a mesma diferenciação utilizada por Goulart (1959) para estudo dos transportes tradicionais do Brasil.

5 Os seguintes artigos definiram os padrões técnicos para as obras: "art. 5o - no alinhamento destas Estradas serão preferidas as linhas retas às curvas, salvo quando estas forem muito menos dispendiosas, ou muito mais cômodas aos viajantes, e transporte; art. 6- - estas estradas terão a largura de trinta e cinco palmos, compreendidos os canais, fossos, muros, ou socalcos necessários para sua segurança e duração; art. 7ํ - de cada lado das estradas haverá um espaço de terreno da largura de sessenta palmos, onde as localidades o permitirem, o qual terreno será considerado pertença da estrada, e será posto sob a administração do inspetor geral, que fará cortar todas as árvores, que ali existirem, e proibirá, e efetivamente 
impedirá que dentro dos seus limites se plantem, ou cresçam outras, ou se levantem edifícios, que não sejam os das barreiras; art. 8- estas estradas servirão para carros, e não serão construídas com as atuais calçadas, mas com pequenas pedras quebradas, que não excedam a grandeza de duas polegadas de diâmetro, e segundo a forma mais adotada nos países cultos; art. 9o - a forma da construção será abobadada, de maneira que nas estradas não se demorem as águas das chuvas, que sobre elas caírem imediatamente; art. 10ำ haverá maior cuidado nos reparos, e conservação, delas, empregando continua, e diária atenção reservando sempre aos seus lados materiais necessários para em pronto servirem aos ditos reparos, e conservação; art. 11ํo- se algum terreno oferecer cômoda passagem, sem a construção da estrada pela maneira determinada nesta lei, o inspetor geral se limitará a prover os meios da sua conservação; art. $12^{\circ}-$ as pontes serão de pedra, ou de madeira de lei, segundo aconselharem a economia, duração, e segurança, o leito destas será coberto de pedra, terra, ou areia e não telhados; art. 13o - as pontes de mais de cem palmos de comprimento terão largura para a passagem de dois carros, um ao lado do outro e convirá que nelas se faça um caminho próprio para os peões, ou viandantes de pé; art. 14ํ- estas pontes terão guardas das mesmas independentes, e os seus esteios, e pilares as terão a flor d'água, também deles independente e art. 15으 - a largura de que tratam os artigos sexto, e décimo terceiro só terá lugar onde a circunstâncias locais não oferecem obstáculos tais, que só possam ser superados por exorbitantes despesas" (LLM, lei 18, 1835).

${ }^{6}$ A lei regulamentar definiu que: contratos de empresas provinciais deveriam regular-se por disposições legais que autorizem as mesmas empresas (art. 24) e que nas obras públicas realizadas por administração, deveriam ser preferidos os trabalhadores livres aos escravos (art. 25). Previu-se ainda a futura elaboração de regras que orientassem os contratos de arrematação e empreitada (LLM, Regulamento 39, 1857, p.10).

${ }^{7} \mathrm{O}$ engenheiro chefe deveria cuidar dos trabalhos gráficos, dos estudos preparatórios, planos e orçamentos das obras e transmiti-las ao diretor geral; instruir os engenheiros subordinados; determinar as escalaspadrão para os projetos e os modelos de mapas e papéis; organizar e apresentar ao diretor-geral as instruções para execução, na parte técnica, dos trabalhos a serem implementados pelos executores das obras; fiscalizar a execução das obras em qualquer parte da província; fazer levantar mapa das estradas principais e respectivos ramais da província com indicação dos lugares para construção de novas obras e recebedorias; fazer pedidos dos utensílios necessários aos outros engenheiros; designar os engenheiros; ajustar, demitir e despedir feitores, operários e serventes; organizar as folhas de pagamentos do pessoal e do material empregados nas obras realizadas por administração e apresentá-las ao diretor-geral; aperfeiçoar a carta corográfica da província e apresentar anualmente ao diretor-geral relatório das atividades da seção (LLM, Regulamento 53, 1866, p.30-33).

${ }^{8}$ Os termos profissão/profissional são usados para designar indivíduos que realizam algum tipo de trabalho moderno e especializado no qual a educação superior e o conhecimento abstrato que ela transmite são pré-requisitos (Freidson, 1994, p.24).

${ }^{9}$ Por desenhos entendiam: plantas gerais e as parciais da obra. Por memória: justificativa da utilidade e conveniência da obra, as circunstâncias locais em que ela tiver relação, quer na parte científica, quer na econômica da construção; a descrição minuciosa do projeto com referência aos desenhos; as condições técnicas que devem ser observadas, para ser o projeto executado com solidez, perfeição e economia; o tempo necessário para conclusão; a tarifa de preços elementares dos materiais e mão de obra e a relação das máquinas para alugar ou adquirir; a tarifa de preços composta de cada unidade da obra; a avaliação da extensão linear das superfícies e dos volumes que representam as diversas quantidades de obra a executar-se e o orçamento propriamente dito. Quando os projetos fossem para abertura de estradas: a descrição da natureza do terreno; a extensão e largura da estrada; o todo dela ou a parte compreendida dentro de determinado município; as declividades do terreno; o número de pontes, pontilhões, bueiros e sarjetas e todas as circunstâncias que pudessem influir na construção (LLM, Regulamento 87, 1879).

${ }^{10}$ Em 1882, para enfrentar o problema de empregar os egressos da Escola de Minas de Ouro Preto, Charles Henry Gorceix, diretor da instituição, acrescentou um ano à formação, para introdução de cadeiras de estradas de ferro, resistência de materiais e construção. Passo inicial rumo à criação da engenharia civil na Escola. Em 1885 todo o curso foi reformulado, sua duração passou para seis anos, e os engenheiros ganharam as regalias e os direitos de engenheiros civis (Carvalho, 2002, p.67).

${ }^{11}$ Essa quantificação foi obtida por meio de sistematização e codificação, em banco de dados eletrônico, das informações constantes no inventário realizado no Arquivo Público Mineiro, diretamente dos originais manuscritos, para todos os "Processos de construção de estradas e pontes" remanescentes. Assim, foram definidas as seguintes variáveis: (a) tipo de obra - 1. estrada ou 2. ponte (variável que classifica o processo por tipo de obra); (b) número da caixa (variável com número de identificação da caixa no Arquivo Público Mineiro); (c) Número do processo (variável que indica o número do processo da caixa); (d) 
circunscrição (variável que classifica o nome da localidade onde foi produzido o documento); (e) instância (variável que classifica o status administrativo da localidade onde foi produzido o documento); (f) destinatário (variável que classifica a função administrativa do destinatário do documento ou nome dos engenheiros), (g) remetente (variável que classifica a função administrativa do autor do documento ou nome dos engenheiros); (h) assunto I (variável que classifica o tema do documento); (i) assunto II (variável que especifica o nome obra) e (j) nome dos atores (variável que classifica todos os nomes constantes nos documentos; Barbosa, 2009).

${ }^{12}$ No Arquivo Público Mineiro há fundo arquivístico exclusivo sobre Halfeld.

\section{REFERÊNCIAS}

ALMEIDA, Carla Maria C.

Minas Gerais de 1750 a 1850: bases da economia e tentativa de periodização. $L P H$ : Revista de História, Mariana, n.5, p.88-112. 1995.

BARBOSA, Daniel H. Diniz.

Os técnicos em ação: os engenheiros de Minas e as alternativas de desenvolvimento regional, 1935-1945. Dissertação (Mestrado) - Faculdade de Filosofia e Ciências Humanas, Universidade Federal de Minas Gerais, Belo Horizonte. 2005.

BARBOSA, Lidiany Silva.

Transportes em Minas Gerais, 1835-1889. 2009. Exame de qualificação (Doutorado) - Instituto de Filosofia e Ciências Sociais, Universidade Federal do Rio de Janeiro, Rio de Janeiro. 2009.

BARBOSA, Lidiany Silva.

Processos de construção de estradas e pontes: edificação e manutenção da rede viária da província de Minas Gerais. In: Seminário Latino-americano de Arquitetura e Documentação, 2008, Belo Horizonte. Anais... Belo Horizonte: UFMG. 2008.

BARBOSA, Maria Lígia de O.

Reconstruindo as Minas e planejando as Gerais: os engenheiros e a constituição dos grupos sociais Tese (Doutorado) - Instituto de Filosofia e Ciências Humanas, Universidade Estadual de Campinas, Campinas. 1993.

BASTOS, Wilson de Lima.

O engenheiro Henrique Guilherme Fernando Halfeld: sua vida, sua obra, sua descendência. Juiz de Fora: Paraibuna. 1975.

BLAKE, Augusto Victoriano Alves Sacramento. Diccionario bibliographico brazileiro. v.3. Rio de Janeiro: Typographia Nacional. p.223-224. 1895.

\section{BRASIL.}

Lei Imperial de 29 de agosto de 1828. Estabelece regras para a construcção das obras publicas, que tiverem por objecto a navegação de rios, abertura de cannaes, edificação de estradas, pontes, calçadas o aqueductos. 29 ago. 1828 . Disponível em: http://www6.senado.gov.br/
legislacao/ListaPublicacoes.action?id= 81651\&tipoDocumento=LEI\& tipoTexto=PUB. Acesso em: 3 ago. 2011.

CARRARA, Ângelo Alves. Agricultura e pecuária na capitania de Minas Gerais (1674-1807). Tese (Doutorado) Instituto de Filosofia e Ciências Sociais, Universidade Federal do Rio de Janeiro, Rio de Janeiro. 1997.

CARVALHO, J. Murilo de.

A Escola de Minas de Ouro Preto: o peso da glória. 2.ed. Belo Horizonte: Editora da UFMG. 2002.

CHAVES, Cláudia Maria das Graças. Perfeitos negociantes: mercadores das minas setecentistas. São Paulo: Annablume. 1999.

COELHO, Edmundo Campos.

As profissões imperiais: medicina, advocacia e engenharia no Rio de Janeiro, 1822-1930. Rio de Janeiro: Record. 1999.

COSTA FILHO, Miguel.

A cana-de-açúcar em Minas Gerais. Rio de Janeiro: Instituto do Açúcar e do Álcool. 1963.

FREIDSON, Eliot.

Renascimento do profissionalismo. São Paulo: Editora da USP. 1994.

GODOY, Marcelo Magalhães.

Intrépidos viajantes e a construção do espaço: uma proposta de regionalização para as Minas Gerais do século XIX. Texto para discussão n.109. Belo Horizonte: Cedeplar/UFMG. 1996.

GOULART, José Alípio.

Meios e instrumentos de transportes no interior do Brasil. Rio de Janeiro: Ministério da Educação e Cultura. 1959.

GOUVÊA, Maria de Fátima.

O Império das províncias: Rio de Janeiro, 1822-1889. Rio de Janeiro: Civilização Brasileira. 2008.

HOLANDA, Sérgio Buarque de.

Metais e pedras preciosas. In: Holanda, Sérgio Buarque (Org.). História geral da civilização 
brasileira. Rio de Janeiro: Bertrand Brasil. v.2, p.259-311. 2001.

IGLESIAS, Francisco.

Política econômica do governo provincial mineiro, 1835-1889. Rio de Janeiro: Ministério da Educação e Cultura; Instituto Nacional do Livro. 1958.

KULA, Witold.

Problemas y métodos de la historia económica. Barcelona: Península. 1974.

LENHARO, Alcir.

As tropas da moderação: o abastecimento da Corte na formação política do Brasil, 18081842. 2.ed. Rio de Janeiro: Secretaria Municipal de Cultura, Turismo e Esportes. 1979.

LIBBY, Douglas Cole.

Transformação e trabalho. São Paulo: Brasiliense. 1988.

LLM.

Livro da Lei Mineira. (Coleção do Arquivo Público Mineiro). 1835-1889.

MARTINS, Roberto Borges.

Ensaio crítico. Tschudi, Halfeld, Wagner e a geografia de Minas Gerais no século XIX. Em: Halfeld, H. G. F.; Tschudi, J. J. V. A província brasileira de Minas Gerais. Belo Horizonte: Fundação João Pinheiro. p.15-60. 1998.

MARTINS, Roberto Borges.

Minas Gerais, século XIX: tráfico e apego à escravidão numa economia não exportadora. Estudos Econômicos, São Paulo, v.13, n.1, p.181-209. 1983.

PAIVA, Clotilde Andrade.

População e economia: Minas Gerais no século XIX. Tese (Doutorado) - Faculdade de Filosofia, Letras e Ciências Humanas, Universidade de São Paulo, São Paulo. 1996.

PAULA, Armênio José de; FERREIRA, Saturnino G. (Org.).

Precursores e figuras notáveis de Minas Gerais. Belo Horizonte: Editora SãoVicente. 1974.

PAULA, João Antônio de.

Raízes da modernidade em Minas Gerais. Belo Horizonte: Autêntica. 2000.

PCE.

Processos de construção de estradas. Seção Provincial, Obras Públicas; caixa 2. (Arquivo Público Mineiro). 1835-1889.

PCP.

Processos de construção de pontes. Seção Provincial, Obras Públicas; caixa 45, doc. 7/1. (Arquivo Público Mineiro). 1835.
QUEIROZ, Paulo Roberto Cimó.

Transportes e comunicações no Brasil: breves considerações sobre as fontes para sua história. América Latina en la historia económica, México, n.14, p.115-136. Ene.-dic. 2000.

REIS, Abel.

Pela elaboração da história da engenharia no Brasil. Revista Mineira de Engenharia, Belo Horizonte, ano 4, n.35-36, p.25. 1942.

RIVERA, Bueno de.

Pioneiros e expoentes de Minas Gerais. Belo Horizonte: Guia Rivera. 1971.

RODARTE, Mario Marcos Sampaio.

O caso das minas que não se esgotaram: a pertinácia do antigo núcleo central minerador na expansão da malha urbana da Minas Gerais oitocentista. Dissertação (Mestrado) - Centro de Desenvolvimento e Planejamento Regional, Universidade Federal de Minas Gerais, Belo Horizonte. 1999.

ROQUE, Rita de Cássia Menezes.

Os bandeirantes dos tempos modernos: a Escola de Minas de Ouro Preto e o bloco no poder em Minas, 1889-1945. Dissertação (Mestrado) Centro de Estudos Gerais, Universidade Federal Fluminense,

Niterói. 1999.

SANTOS, Paulo Coelho Mesquita. O Brasil nas exposições universais, 1862-1911: mineração, negócios e publicações. Dissertação (Mestrado) - Instituto de Geociências,

Universidade Estadual de Campinas, Campinas. 2009.

\section{SHINN, Terry.}

Des corps de l'Etat au secteur industriel: genèse de la profession d'ingenieur, 1750-1920. Revue Française de Sociologie, Paris, v.19, n.1, p.39-71. 1978.

TELLES, Pedro Carlos da Silva.

Um pioneirismo em normalização técnica em 1876. Revista da Sociedade Brasileira de História da Ciência, Rio de Janeiro, n.9, p.77-78. 1993.

TÔRRES, João Camilo de. História de Minas Gerais. 3.ed. Belo Horizonte: Lemi; Instituto Nacional do Livro. v.1. 1980.

VEIGA, José Xavier da.

Efemérides mineiras, 1664-1897. Belo Horizonte: Fundação João Pinheiro. 1998. 